\title{
Synthesis of New N,O-Acetals 2-Amino-1,4-naphthoquinones Derivatives Under Microwave Irradiation
}

\author{
Alessandro K. Jordão, ${ }^{a}$ David R. da Rocha, ${ }^{a}$ Vitor F. Ferreira ${ }^{\star a}$ \\ aUniversidade Federal Fluminense, Instituto de Química, Departamento de Química Orgânica, 24020-141 \\ Niterói, Rio de Janeiro, Brazil
}

cegvito@vm.uff.br

Keywords: Naphthoquinones, N,O-Acetals, Microwave in organic synthesis

\section{INTRODUCTION}

Naphthoquinones are important natural substances that are widely distributed in different families of plants, fungi and some animals. ${ }^{1}$ The introduction of amino substituents onto the quinone moeity can exert influence on its redox properties, inducing oxidative stress in cells and alkylation of DNA. The aminoquinones are found in important bioactive compounds such as antitumor $^{2}(\mathbf{1})$ and antimalarial ${ }^{3}$ (2) agents.<smiles>O=C1C=C(Nc2ccc(O)cc2)C(=O)c2ccccc21</smiles>

(1)

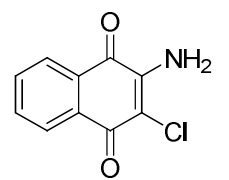

(2)
Figure 1. Examples of bioactive aminonaphthoquinones.

\section{RESULTS AND DISCUSSION}

The aim of this work is the synthesis of a new series of N,O-acetals 2-amino-1,4-naphthoquinone derivatives to evaluate biological activity. N,Oacetals are related by Barluenga and co-workers ${ }^{4}$ as compounds unstable at room temperature that need to be stored at $-18^{\circ} \mathrm{C}$ to avoid decomposition. Herein we describe a methodology employing microwave irradiation to obtain in satisfactory yields stables $\mathrm{N}, \mathrm{O}$-acetals. In the first step 1,4-naphthoquinone (3) was used as the starting material, which was reacted with sodium azide in acetic acid to produce 2-amino-1,4-naphthoquinone (4). ${ }^{5}$ Addition Reaction of 4 with paraformaldehyde in the presence of alcohols under microwave irradiation formed the $\mathrm{N}, \mathrm{O}$-acetals in moderate yields (Scheme 1).

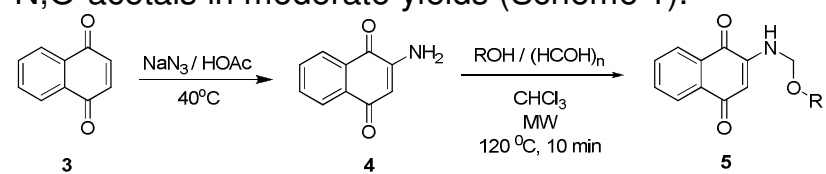

Scheme 1. Synthesis of N,O-acetals of 2-amino-1,4naphthoquinones 5a-e.

Exploring this reaction, it was possible to prepare in moderate to good yields $\mathrm{N}, \mathrm{O}$-acetals 2-amino-1,4naphthoquinones derivatives (5a-e), which are shown in the Table 1.

$14^{\text {th }}$ Brazilian Meeting on Organic Synthesis $-14^{\text {th }}$ BMOS - September 01-05, 2011-Brasilia, Brazil
The reactions were performed in a closed glass vessel in chloroform. These compounds were characterized by spectroscopic methods such as ${ }^{1} \mathrm{H}$ and ${ }^{13} \mathrm{C}$ NMR. This is the first example of stables $\mathrm{N}, \mathrm{O}$-acetals naphthoquinones and the compounds synthesized are very promising for biological activity screenings.

Table 1. Yields of the N,O-acetals of 2-amino-1,4naphthoquinones 5a-e

\begin{tabular}{|c|c|c|}
\hline Product & $\mathbf{R}$ & $\begin{array}{c}\text { Yield } \\
\text { (\%) }\end{array}$ \\
\hline $\mathbf{5 a}$ & $-\mathrm{CH}_{3}$ & 74 \\
\hline $\mathbf{5 b}$ & $-\mathrm{CH}_{2} \mathrm{CH}_{3}$ & 47 \\
\hline $\mathbf{5 c}$ & $-\mathrm{CH}_{2} \mathrm{C}_{6} \mathrm{H}_{5}$ & 45 \\
\hline $\mathbf{5 d}$ & $-\mathrm{C} \equiv \mathrm{CH}$ & 21 \\
\hline $\mathbf{5 e}$ & $\begin{array}{c}\text { (Methyl-5'-deoxy-2',3'-O- } \\
\text { isopropylidene- } 3-D- \\
\text { ribofuranosid-5'-yl) }\end{array}$ & 35 \\
\hline
\end{tabular}

\section{CONCLUSION}

In summary, we reported herein the synthesis of a novel series of $\mathrm{N}, \mathrm{O}$-acetals 2-amino-1,4naphthoquinones derivatives under microwave irradiation.

\section{ACKNOWLEDGEMENTS}

\section{CNPq, FAPERJ-PRONEX, FINEP e CAPES-PNPD}

\section{REFERENCES}

${ }^{1}$ Franco, C. F. J.; Jordão, A. K.; Ferreira, V. F.; Pinto, A. C.; de Souza, M. C. B. V.; Resende, J. A. L. C.; Cunha, A. C. J. Braz. Chem. Soc. 2011, 22 , 187.

${ }^{2}$ Benites, J.; Valderrama, J A.; Bettega, K.; Pedrosa, R. C.; Calderon, P.

B.; Verrax, J. Eur. J. Med. Chem. 2010, 45, 6052.

3 Kapadia, G. J.; Azuine, M. A.; Balasubramanian, V.; Sridhar, R. Pharmacol. Res. 2001, 43, 363.

${ }^{4}$ Barluenga, J.; Bayón, A M.; Campos, P.; Asensio, G.; Gonzalez-Nuñez,

E.; Molina, Y. J. J. Chem. Soc. Perkin. Trans. / 1988, 1631

${ }^{5}$ Fieser, L. F.; Hartwell, J. L. J. Am. Chem. Soc. 1935, 57, 1482. 